\title{
Implementasi Tematik Integratif Kurikulum 2013 di Sekolah Dasar
}

\author{
Shelvia Devi Demonika ${ }^{1}$, Ali Mustadi ${ }^{1}$, Inang Irma Rezkillah ${ }^{1}$ \\ ${ }^{1}$ Pendidikan Dasar-Universitas Negeri Yogyakarta
}

\section{INFO ARTIKEL}

\section{Riwayat Artikel:}

Diterima: $30-12-2019$

Disetujui: 19-06-2020

\section{Kata kunci:}

thematic integrative; 2013 curriculum; primary school; tematik integratif; kurikulum 2013; sekolah dasar

\section{ABSTRAK}

\begin{abstract}
This study aims to describe and interpret learning planning and obstacles in the implementation of the 2013 curriculum in elementary schools throughout Depok sub-district, Sleman Regency, Yogyakarta. It is a qualitative research type of phenomenology. The subjects of this study consisted of principals, classroom teachers, and students from Depok sub-district. Data collection is carried out through observation, interviews, and documentation. The results of the study showed that the teachers had compiled syllabuses and lesson plans in accordance with the themes and sub-themes determined.
\end{abstract}

\begin{abstract}
Abstrak: Penelitian ini bertujuan untuk mendeskripsikan dan memaknai perencanaan pembelajaran, serta hambatan yang ditemui dalam implementasi Kurikulum 2013 di Sekolah Dasar Se-Kecamatan Depok, Kabupaten Sleman, Daerah Istimewa Yogyakarta. Penelitian ini merupakan penelitian kualitatif jenis phenomenologi. Subjek penelitian ini terdiri dari kepala sekolah, guru kelas, dan siswa se-Kecamatan Depok. Teknik pengumpulan data yang digunakan adalah observasi, wawancara, dan dokumentasi. Berdasarkan hasil penelitian menunjukkan bahwa dalam kegiatan pembelajaran, guru telah menyusun Silabus dan RPP disesuaikan dengan tema dan sub tema yang telah dibuat oleh pemerintah.
\end{abstract}

\author{
Alamat Korespondensi: \\ Shelvia Devi Demonika \\ Pendidikan Dasar \\ Universitas Negeri Yogyakarta \\ Jalan Colombo No. 1, Karangmalang, Yogyakarta \\ E-mail: shelvia0006pasca.2019@student.uny.ac.id
}

Pendidikan merupakan bagian yang terpenting dalam kehidupan suatu negara. Berdasarkan Undang-Undang Republik Indonesia Tentang Guru dan Dosen tercantum bahwa pembangunan nasional dalam bidang pendidikan bertujuan untuk mencerdaskan kehidupan bangsa serta meningkatkan kualitas manusia Indonesia yang beriman, bertakwa, berakhlak mulia, dan menguasai ilmu pengetahuan dalam mewujudkan masyarakat maju, adil, makmur, serta beradab berdasarkan Pancasila dan Undang-Undang Negara Republik Indonesia Tahun 1945 (Republik Indonesia, 2005). Suatu negara akan maju jika memiliki sumber daya manusia yang berkualitas, begitu pula Indonesia. Salah satu langkah upaya membentuk sumber daya manusia berkualitas yaitu dengan memberikan pendidikan yang layak bagi seluruh rakyat Indonesia. Pendidikan dapat dikatakan layak apabila mampu mengembangkan potensi serta mencetak peserta didik menjadi seseorang yang berkualitas dan unggul.

Dalam membangun kualitas sumber daya manusia, Indonesia telah berupaya mendukung adanya pelaksanaan pendidikan menengah atau rintisan wajib belajar selama 12 tahun melalui suatu program yaitu Program Indonesia Pintar atau sering disebut PIP (Kementerian Pendidikan dan Kebudayaan, 2016). Program pendidikan tersebut dilakukan secara formal. Pendidikan formal yang disediakan oleh pemerintah telah banyak mengalami perubahan, hal ini disesuaikan dengan tantangan yang akan dihadapi pada masa yang akan datang sebagai penerus bangsa. Perubahan pendidikan formal yang terjadi belakangan ini salah satunya perubahan pada Kurikulum Tingkat Satuan Pendidikan (KTSP) yang diubah menjadi Kurikulum 2013.

Kurikulum berdasarkan Undang-Undang Republik Indonesia Nomor 20 Tahun 2003 (UU RI NO 20, 2003) yaitu berisikan rencana serta pengaturan mengenai tujuan, isi, dan bahan pelajaran, serta cara yang digunakan sebagaimana pedoman penyelenggaraan kegiatan pembelajaran untuk mencapai suatu tujuan pendidikan nasional. Kurikulum 2013 merupakan pengembangan dari kurikulum yang sebelumnya, baik Kurikulum yang telah dirintis pada tahun 2004 maupun Kurikulum Tingkat Satuan Pendidikan pada tahun 2006. Hanya saja, yang menjadi titik tekan pada Kurikulum 2013 yaitu adanya peningkatan dan keseimbangan antara soft skill dan hard skill, meliputi aspek kompetensi sikap, keterampilan, dan pengetahuan peserta didik (Auliyana, Akbar, \& Yuniastuti, 2018).

Perubahan kurikulum terjadi karena beberapa aspek yang dipertimbangkan oleh pemerintah. Berdasarkan hasil Programme for Internasional Stundent Assesment (PISA) tahun 2018 akumulasi perolehan skor rata-rata dalam pencapaian sains, membaca, dan matematika hanya 1.146 poin dan berada pada peringkat 71 dari 78 negara, angka ini turun 3,4 persen dibanding dengan hasil PISA tahun 2015 (OECD, 2018). Faktor penyebab Indonesia menempati posisi tersebut dikarenakan 
terdapat materi dalam PISA yang tidak dipelajari. Materi-materi tersebut salah satunya terkait dengan pembentukan karakter serta mampu menyelesaikan permasalahan yang terjadi dalam keseharian peserta didik (Pratiwi, 2019). Dengan melihat hasil PISA tersebut, perlu adanya keterampilan abad 21. Keterampilan-keterampilan pada abad 21 yang dibutuhkan peserta didik terdiri dari kualitas karakter, literasi dasar, dan kompetensi. Kualitas Pendidikan karakter yang diterapkan harus sesuai pada lima nilai utama karakter Penguatan Pendidikan Karakter (PPK) yang terdiri atas (1) religius, (2) nasionalis, (3) gotong royong, (4) mandiri, dan (5) integritas (Kemendikbud, 2017). Keterampilan literasi dasar yang harus dimiliki, yaitu (1) kemampuan baca dan tulis, (2) kemampuan numerasi, (3) kemampuan sains, (4) kemampuan digital, (5) kemampuan finansial, dan (6) kemampuan budaya dan kewargaan (Kementerian Pendidikan dan Kebudayaan, 2017). Peserta didik juga diharapkan memiliki empat kompetensi atau yang disebut 4C terdiri atas Critical Thinking Skills, Creative thinking, Communication, dan Collaboration (Trilling \& Fadel, 2010).

Kompetensi yang harus dimiliki siswa untuk menghadapi tantangan abad 21 memiliki kesinambungan dengan model kurikulum yang digunakan dalam Kurikulum 2013, perkembangan ilmu pengetahuan kini telah terjadi pergeseran dari segi ciri maupun model pembelajaran yang digunakan (Trilling \& Fadel, 2010). Pergeseran paradigma pendidikan abad 21 terjadi apabila adanya pergeseran pada pola pikir dan pola tindakan dalam konteks penyelenggaraan pendidikan serta konteks pengajaran (Badan Standar Nasional Pendidikan, 2010). Model yang tepat untuk menghadapi abad 21 yaitu model tematik integratif. Model tematik integratif menekankan pembelajaran yang berpusat siswa serta mengusung karakter yang menitikberatkan pada perpaduan dari disiplin ilmu berupa keterampilan, konsep, dan sikap dalam satu topik (Fogarty, 1991). Hal ini sejalan dengan tahap perkembangan anak pada usia 7-15 tahun (operasional konkret) dengan melihat segala sesuatu dengan satuan yang utuh atau holistik (Piaget, 1964). Dari uraian tersebut, Kurikulum 2013 di desain untuk mempersiapkan masyarakat agar memiliki kemampuan produktif, kreatif, inovatif, dan afektif melalui penguatan dalam bidang pengetahuan, keterampilan dan sikap. Untuk mencapai tujuan dikembangkannya Kurikulum 2013 salah satunya perlu memperhatikan proses perencanaannya dalam penerapan Kurikulum 2013 di lapangan. Penelitian ini berfokus pada penerapan perencanaan tematik integratif di sekolah dasar Se-Kecamatan Depok.

Berdasarkan Peraturan Menteri Pendidikan dan Kebudayaan (Permendibud) Nomor 65 Tahun 2013 Bab III tentang Standar Proses Pendidikan Dasar dan Menengah berisikan mengenai proses pembelajaran yang dirancang dalam bentuk Silabus dan Rencana Pelaksanaan Pembelajaran yang mengacu pada Standar Isi (Kementerian Pendidikan dan Kebudayaan, 2013). Silabus merupakan acuan dari kerangka pembelajaran untuk tiap bahan kajian. Silabus memuat komponen berupa (1) identitas mata pelajaran, (2) identitas sekolah, (3) kompetensi inti, (4) kompetensi dasar, (5) tema, (6) materi pokok, (7) pembelajaran, (8) penilaian, (9) alokasi waktu, dan (10) sumber belajar. Rencana Pelaksanaan Pembelajaran (RPP) adalah rencana kegiatan pembelajaran tatap muka untuk satu pertemuan atau lebih. RPP dikembangkan dari silabus yang telah dibuat untuk mengarahkan kegiatan pembelajaran peserta didik dalam upaya mencapai Kompetensi Dasar (KD). Komponen RPP, meliputi (1) identitas sekolah, (2) identitas mata pelajaran, (3) kelas/semester, (4) materi pokok, (5) alokasi waktu, (6) tujuan pembelajaran, (7) kompetensi dasar dan indikator pencapaian kompetensi, (8) materi pembelajaran, (9) metode pembelajaran, (10) media pembelajaran, (11) sumber belajar, (12) langkah-langkah pembelajaran, dan (13) penilaian hasil belajar.

Berdasarkan Permendikbud RI No. 81A tahun 2013 (Fallis, 2013) menerangkan mengenai standar proses pelaksanaan dalam pembelajaran terdiri atas kegiatan pendahuluan, kegiatan inti, dan kegiatan penutup. Pada bagian kegiatan pendahuluan terdiri atas (1) mempersiapkan siswa secara mental dan fisik; (2) melakukan apersepsi; (3) menyajikan permasalahan atau tugas yang akan dilakukan; (4) menyajikan cakupan materi beserta penjelasannya tentang kegiatan-kegiatan yang akan dilakukan oleh siswa. Pada kegiatan inti, proses pembelajaran yang dilakukan harus interaktif, inspiratif, menyenangkan, menantang, memotivasi, dan memberikan ruang kepada siswa untuk memiliki kreasi sendiri yang disesuaikan dengan bakat, minat, dan perkembangan psikologis maupun fisik. Dalam kegiatan siswa, guru harus memperhatikan kompetensi-kompetensi yang terkait dengan sikap sesuai dengan RPP yang telah dirancang. Pada kegiatan penutup, guru dan siswa membuat rangkuman mengenai pelajaran, melakukan kegiatan penilaian, merencanakan tindak lanjut, serta menyampaikan rencana untuk pembelajaran berikutnya.

Pembelajaran K13 semula diterapkan secara terbatas pada kelas I dan IV SD. Pada wilayah Daerah Istimewa Yogyakarta terutama Sekolah Dasar Se-Kecamatan Depok, Sleman, mulai menerapkan pembelajaran K13 pada tahun 2014. Penerapan Kurikulum 2013 di sekolah dasar mendapatkan perhatian dari pemerintah dalam segi sarana prasarana dan guru sebagai fasilitator juga tidak luput dari perhatian pemerintah dengan diberikannya pelatihan. Berdasarkan uraian di atas, pertanyaan penelitian yaitu Bagaimana penerapan perencanaan kurikulum 2013 sekolah dasar Kecamatan Depok, Sleman berdasarkan aspek tematik integratif?

\section{METODE}

Penelitian ini termasuk kualitatif jenis phenomomenalogy. Tujuan penelitian ini yaitu untuk mengetahui penerapan perencanaan pembelajaran tematik integratif Kurikulum 2013 sekolah dasar se-Kecamatan Depok. Subjek penelitian ini yaitu kepala sekolah, guru, dan siswa sekolah dasar se-Kecamatan Depok karena sudah menerapkan kurikulum 2013 selama lebih dari lima tahun. Penelitian dilangsungkan pada November 2019. 
Teknik pengumpulan data diperoleh dengan melakukan wawancara yang mendalam (Yin \& Yin, 2011). Observasi menggunakan anekdot selama proses tematik integratif implementasi 2013, peneliti berlaku hanya sebagai pengamat sekaligus berusaha menjadi bagian dari kelompok sehingga kesan subjektif dapat diminimalisirkan. Triangulasi teknik dan triangulasi sumber digunakan sebagai teknik pemeriksaan keabsahan data. Instrumen pengumpulan data menggunakan lembar observasi dan pedoman wawancara. Berikut ini kisi-kisi pedoman wawancara tentang penerapan tematik integratif K13.

Tabel 1. kisi-kisi wawancara mendalam tentang Implementasi Tematik Integratif Kurikulum 2013

\begin{tabular}{cl}
\hline \multicolumn{1}{c}{ Variabel } & Indikator \\
\hline \multirow{3}{*}{ Tematik Integratif } & Tema \\
& RPP \\
& Bahan ajar \\
\hline
\end{tabular}

Peneliti menggunakan teknik analisis interaktif yang terdiri atas data Collection, condesation, display data, serta Conclution drawing and verification (Miles et al., 2014). Proses tidak "sekali jadi", melainkan perlu adanya interaksi secara bolak balik. Perkembangan bersifat sekuensial dan interaktif. Dalam penelitian jenis kualitatif, validasi diperlukan untuk pemeriksaan akurasi hasil dari penelitian (Creswell, 2014).

\section{HASIL}

Berdasarkan hasil observasi dan wawancara kepada kepala sekolah, guru, dan siswa tentang implementasi perencanaan pembelajaran tematik integratif Kurikulum 2013 pada sekolah dasar Kecamatan Depok, Sleman, dilihat dari tiga aspek, yaitu tema, Rencana Pelaksanaan Pembelajaran, dan bahan ajar. Tematik integratif yang dilaksanakan di sekolah dasar artinya dalam proses pembelajaran memadukan beberapa aspek. Dengan memadukan ketiga aspek tersebut, siswa mendapatkan pengetahuan, keterampilan, dan sikap secara utuh. Dituturkan oleh salah satu kepala sekolah sebagai narasumber yang menyebutkan bahwa "Sekolah kami sudah menerapkan kurikulum 2013 sejak tahun 2014 yang dilakukan secara bertahap, uji coba pertama kali dilakukan pada kelas I dan IV, kemudian pada kelas II dan V, dan tahap akhir pada kelas III dan VI, pembelajarannya menerapkan model tematik integratif dengan kegiatan mencakup pemilihan tema; pendekatan pembelajaran yang akan digunakan; penyusunan indikator; pembuatan RPP; penentuan materi; penilaian; pembuatan media pembelajaran yang efektif'.

Dalam aspek pemilihan tema, diungkapkan oleh kepala sekolah "Tema yang diterapkan sudah dipilihkan dan ditetapkan langsung oleh pemerintah". Kemudian dalam aspek pembuatan Rencana Pelaksanaan Pembelajaran, guru dapat melakukannya secara mandiri maupun secara kelompok. Hal ini diungkapkan oleh salah seorang guru "Sejak awal penerapan Kurikulum 2013, RPP kami buat sendiri-sendiri". RPP dibuat guru dan diperiksa oleh kepala sekolah sehari sebelum proses pembelajaran. Hal tersebut diperkuat oleh pernyataan dari salah seorang guru bahwa "Kami biasanya menyusun RPP di hari sebelumnya". Sementara itu, bahan ajar di SD Se-Kecamatan Depok selama ini hanya berpedoman pada buku guru dan buku siswa dari Kemendikbud. Diungkapkan oleh salah satu guru "Kami masih jarang menggunakan bahan ajar selain buku dari Kemendikbud".

Penerapan Kurikulum 2013 banyak menemui hambatan, terutama pada tahap perencanaan. Hambatan ini dikarenakan guru-guru belum mampu beradaptasi dengan kurikulum tersebut. Dituturkan oleh kepala sekolah bahwa "Sudah sejak awal dalam penerapan Kurikulum 2013, Kami menemui banyak kendala yang harus dihadapi, mulai dari penyusunan RPP hingga pemilihan media pembelajaran. Kendala-kendala tersebut dapat kami atasi dengan mengikuti pelatihan yang diadakan langsung oleh pemerintah". Usaha lain yang dapat dilakukan oleh sekolah untuk memperkuat pemahaman mengenai Kurikulum 2013, yaitu dengan mengadakan rapat evaluasi melalui Kelompok Kerja Guru (KKG) yang diperuntukkan bagi seluruh guru seKecamatan Depok, hal ini dituturkan kepala sekolah bahwa "biasanya Kami mengikuti KKG secara rutin untuk memperkuat pemahaman guru-guru mengenai Kurikulum 2013".

\section{PEMBAHASAN}

Penerapan tematik integratif dapat dilihat dari perencanaan yang digunakan. Salah satu faktor penting dalam penerapan kurikulum yaitu adanya perencanaan. Perencanaan dapat digunakan sebagai evaluasi program tersebut dapat tercapai. Pada dasarnya, perencanaan yang ideal adalah proses menata pembelajaran dengan mempertimbangkan berbagai aspek agar pembelajaran aktif, inovatif, kreatif, efektif, dan menyenangkan bagi peserta didik (I Made Alit Mariana, 2018).

Pada sekolah dasar se-Kecamatan Depok, Sleman menerapkan model tematik integratif. Hal ini didukung oleh (Halinen, 2018) bahwa tematik integratif memiliki hubungan dan adanya ketergantungan antara mata pelajaran yang dipelajari di sekolah dengan fenomena kehidupan di luar lingkungan sekolah sehingga pembelajaran lebih bermakna. Tematik terpadu di sekolah dasar dapat dilihat dari proses pembelajaran yang tematik, artinya setiap pembalajaran pada beberapa bidang studi berdiri secara kesatuan yang disebut dengan pembelajaran, sedangkan gabungan dari enam pembelajaran disebut dengan sub tema, dan gabungan dari subtema merupakan tema. Dituturkan oleh kepala sekolah sebagai narasumber yang menyebutkan bahwa "Sekolah kami sudah menerapkan kurikulum 2013 sejak tahun 2014 yang dilakukan secara bertahap, uji coba pertama kali dilakukan pada kelas I dan IV, kemudian pada kelas II dan V, dan tahap akhir pada kelas III dan VI, pembelajarannya 
menerapkan model tematik integratif, dengan kegiatan mencakup pemilihan tema; pendekatan pembelajaran yang akan digunakan; penyusunan indikator; pembuatan RPP; penentuan materi; penilaian; dan pembuatan media pembelajaran yang efektif'. Hal tersebut sejalan dengan (Rasidi \& Setiawati, 2015) yang mengatakan bahwa perencanaan pembelajaran yang dilakukan oleh guru mencakup pemilihan tema yang akan digunakan, pendekatan pembelajaran, menyusun indikator, pembuatan RPP, menentukan materi, dan pembuatan media.

RPP disusun oleh guru kelas masing-masing. Penyusunan tersebut dilakukan secara individual maupun secara kelompok. Diungkapkan oleh salah seorang guru "Sejak awal penerapan Kurikulum 2013, RPP kami buat sendiri-sendiri". Berdasarkan Permendikbud RI No. 81A Tahun 2013 (Fallis, 2013) tentang Penerapan K13, dijelaskan pula mengenai prinsip penyusunan RPP, yaitu (1) RPP disusun berdasarkan silabus; (2) RPP disusun berdasarkan kondisi di satuan pendidikan; (3) proses pembelajaran student centered; (4) mengembangkan literasi; (5) memberikan tindak lanjut; (6) RPP memuat program pemberian umpan balik yang positif; (7) adanya keterpaduan antara RPP dengan KI, KD, materi, kegiatan pembelajaran, penilaian, dan sumber belajar; (8) RPP dirancang dengan pertimbangan teknologi informasi dan komunikasi.

Awal penerapan K13 pada Sekolah Dasar se-Kecamatan Depok, para guru mengalami banyak kesulitan. Kesulitan ini dikarenakan guru belum dapat beradaptasi dengan kurikulum tersebut. Sejak awal penerapan Kurikulum 2013, guru dan kepala sekolah terus belajar melalui pelatihan yang diadakan oleh pemerintah, dituturkan kepala sekolah yang menyatakan "Sudah sejak awal dalam penerapan Kurikulum 2013, Kami menemui banyak kendala yang harus dihadapi, mulai dari penyusunan RPP hingga pemilihan media pembelajaran. Kendala-kendala tersebut dapat kami atasi dengan mengikuti pelatihan yang diadakan langsung oleh pemerintah”. Dalam pelatihan tersebut, guru diberikan materi keterampilan menerapkan K13 (Neolaka, Manggoa, \& Nenotek, 2016). Dengan mengikuti pelatihan dan pembinaan, guru dapat meningkatkan kemampuan profesionalisme dalam proses dan hasil belajar (Trianto, 2014). Menurut Sutjipto (2016) seorang guru minimal harus memiliki tiga aspek pengalaman yang didapatkan dari pelatihan, yaitu (1) paham mengenai ide dan desain K13, (2) cara penerapan K13, dan (3) mampu menyampaikan konsep-konsep dari K13.

Usaha lain yang dilakukan oleh sekolah untuk memperkuat pemahaman mengenai Kurikulum 2013, yaitu dengan mengadakan rapat evaluasi melalui Kelompok Kerja Guru (KKG) yang diperuntukan bagi seluruh guru se-Kecamatan Depok, hal ini dituturkan kepala sekolah bahwa "biasanya Kami mengikuti KKG secara rutin untuk memperkuat pemahaman para guru mengenai Kurikulum 2013”. RPP yang dibuat oleh guru dipengaruhi oleh forum KKG. Cara kerja guru pada K13, tidak lagi dilakukan secara individu, namun dilakukan dengan hubungan kolaborasi antarsesama guru melalui forum tersebut. Langkah yang dilakukan guru dalam penyusunan Rencana Pelaksanaan Pembelajaran yaitu penetapan tema dilanjutkan dengan mengkaji buku guru. Dalam proses pengkajian buku guru, proses yang dilakukan adalah menganalisis Standar Kompetensi Lulusan (SKL), Kompetensi Inti (KI), Kompetensi Dasar (KD), dan Indikator. Kompetensi Dasar serta Indikator sudah terdapat dalam buku guru yang berbentuk jarring-jaring tema. Diungkapkan oleh kepala sekolah "Tema yang diterapkan sudah dipilihkan dan ditetapkan langsung oleh pemerintah"

Sekolah Dasar Se-Kecamatan Depok dalam penyusunan RPP melalui tahap (1) memilih tema, pemerintah sudah menetapkan tema secara langsung; (2) mengkaji silabus; (3) menyusun Rencana Pelaksanaan Pembelajaran, tahap ini dirancang guru berdasar dari tema dan sub tema. Dalam penyusunan RPP guru dapat memuat media pembelajaran berdasarkan RPP dan berdasarkan kondisi peserta didik. Rencana Pelaksanaan Pembelajaran yang dirancang guru sehari sebelum pembelajaran dilakukan. Hal tersebut diperkuat oleh pernyataan dari salah satu guru bahwa "Kami biasanya menyusun RPP dan membuat media pembelajaran di hari sebelumnya". Selanjutnya, bahan ajar yang digunakan di SD Se-Kecamatan Depok selama ini hanya berpatokan pada buku dari Kemendikbud. Diungkapkan oleh salah satu guru "Kami masih jarang menggunakan bahan ajar selain dari buku dari Kemendikbud". Bahan ajar bukan hanya berasal dari buku saja, melainkan dapat diartikan sebagai seluruh bentuk bahan yang dapat digunakan dalam mendukung guru melaksanakan KBM (Pendidikan, 2006). Pelaksanaan tematik integratif di sekolah dasar menuntut adanya bahan ajar yang layak (Perwitasari, Wahjoedi, \& Akbar, 2018). Bahan ajar dapat dikembangkan sesuai dengan tuntutan K13 dengan meninjau kebutuhan dari siswa (Asriani, Sa'dijah, \& Akbar 2017).

Implementasi tematik integratif K13 di SD Se-Kecamatan Depok, secara umum guru mampu melakukan pembelajaran yang sesuai dengan pembelajaran tematik integratif. Hal tersebut dapat dibuktikan dengan tidak terlihatnya pemisahan tiap mata pelajaran yang dipadukan, dan sudah menggunakan tema yang telah ditentukan oleh pemerintah dalam setiap pembelajarannya. Namun, dalam pelaksanaan tematik integratif Kurikulum 2013, didapati beberapa hambatan guru, salah satunya yaitu penyusunan RPP. Kendala dihadapi sebagian guru dalam penyusunan RPP yaitu dalam mengembangkan media sumber belajar yang tepat dengan situasi kondisi lingkungan siswa. Berdasarkan Permendikbud RI No. 65 tahun 2013, sumber belajar mencakup buku, media cetak atau elektronik, alam sekitar, dan sumber belajar lain yang layak (Kemendikbud, 2013). Media yang dikembangkan guru terkadang tidak mampu membuat siswa lebih aktif. Hal tersebut membuat guru merasa kesulitan dalam pemilihan media yang tepat sebagai sarana mempermudah dalam proses pembelajaran. Upaya mengatasi hambatan dalam pemilihan media sumber belajar yang tepat, guru dapat mengikuti lokakarya/seminar (Sakti \& Wijayanti, 2014). Lokakarya adalah diskusi yang dilakukan para pakar untuk membicarakan permasalahan yang berhubungan dengan bidang keahliannya. Para guru dapat mengundang ahli di bidang pembelajaran tematik untuk mengatasi hambatan dalam mengimplementasikan pembelajaran tematik, khususnya dalam permasalahan media sumber belajar yang tepat bagi peserta didik. Untuk dapat mengimplementasikan tematik integratif Kurikulum 2013, Kristiantari (2015) menyatakan bahwa 97,57\% guru-guru mempunyai harapan yang tinggi agar diberikannya pelatihan/seminar. 


\section{SIMPULAN}

Berdasarkan hasil uraian penjelasan penelitian diperoleh simpulan bahwa sebagian guru sudah memiliki pemahaman K13 mengenai perangkat pembelajaran yang disusun guru Sekolah Dasar Se-Kecamatan Depok yang dilakukan dengan individual maupun dalam forum Kelompok Kerja Guru (KKG). Namun, beberapa guru masih kesulitan dalam pengembangan media dan bahan ajar yang efektif dan efisien untuk peserta didik. Berdasarkan kesimpulan tersebut, peneliti mengemukakan saran mengenai permasalahan pemilihan dan pembuatan media pembelajaran yang belum efektif untuk siswa, yaitu dengan cara guru dapat mensiasati melalui pencarian video pembelajaran mengenai media yang akan dibuat beserta cara kerja alat tersebut. Selain itu, guru dapat mengikuti seminar/pelatihan yang berhubungan dengan media pembelajaran siswa sekolah dasar.

\section{DAFTAR RUJUKAN}

Auliyana, N., Akbar, S., \& Yuniastuti. (2018). Penerapan Pembelajaran Tematik Terpadu di Sekolah Dasar. Jurnal Pendidikan: Teori, Penelitian, dan Pengembangan, 3(12), 1572-1582.

Asriani, P., Sa'dijah, C., \& Akbar, S. (2017). Bahan Ajar Berbasis Pendidikan Karakter untuk Siswa Kelas IV Sekolah Dasar. Jurnal Pendidikan: Teori, Penelitian, dan Pengembangan, 2(11), 1456-1468.

Badan Standar Nasional Pendidikan. (2010). Paradigma Pendidikan Nasional Abad XXI. Paradigma Pendidikan Nasional Abad $X X I$.

Creswell, J. W. (2014). Research Design: Qualitative, Quantitative, and Mixed Methods Approaches. 4th Edition. In SAGE Publication. https://doi.org/10.1007/s13398-014-0173-7.2

Halinen, I. (2018). The New Educational Curriculum in Finland. In Improving the quality of Childhood in Europe.

Katuuk, D. A. (2014). Manajemen Implementasi Kurikulum: Strategi Penguatan Implementasi Kurikulum 2013. Jurnal Cakrawala Pendidikan, 33(1), 13-26. https://doi.org/10.21831/cp.v1i1.1858

Kementerian Pendidikan dan Kebudayaan. (2013). Standar Proses Pendidikan Dasar dan Menengah. Peraturan Menteri Pendidikan dan Kebudayaan Republik Indonesia Nomor 65 Tahun 2013.

Kementerian Pendidikan dan Kebudayaan. (2016). Peraturan Menteri Pendidikan dan Kebudayaan RI Tahun 2016 tentang Program Indonesia Pintar.

Kristiantari, R. M. (2015). Analisis Kesiapan Guru Sekolah Dasar dalam Mengimplementasikan Pembelajaran Tematik Integratif Menyongsong Kurikulum 2013. Jurnal Pendidikan Indonesia, 3(2), 460-470. https://doi.org/10.23887/jpiundiksha.v3i2.4462

Miles, M. B., Michael Huberman, A., \& Saldaña, J. (2014). Qualitative Data Analysis: A Methods Sourcebook (3rd Edition). In SAGE Publications, Inc. https://doi.org/10.1177/239700221402800402

Neolaka, F., Manggoa, M., \& Nenotek, S. (2016). Implementasi Kurikulum 2013 di SMP Negeri 1 Kupang Tengah Kabupaten Kupang Tahun Ajaran 2013/2014. Jurnal Pendidikan: Teori, Penelitian, dan Pengembangan, 1(10), 2010-2015. https://doi.org/10.17977/jp.v1i10.7410

OECD. (2018). PISA 2018 Results. Combined Executive Summaries. Journal of Chemical Information and Modeling, 53(9), 1689-1699. https://doi.org/10.1017/CBO9781107415324.004

Perwitasari, S., Wahjoedi, \& Akbar, S. (2018). Pengembangan Bahan Ajar Tematik Berbasis Kontekstual. Jurnal Pendidikan: Teori, Penelitian, dan Pengembangan, 3(3), 278-285.

Piaget, J. (1964). Part I: Cognitive Development in Children: Piaget Development and Learning. Journal of Research in Science Teaching. https://doi.org/10.1002/tea.3660020306

Pratiwi, I. (2019). Efek Program PISA terhadap Kurikulum di Indonesia. Jurnal Pendidikan dan Kebudayaan, 4(1), 51-71. https://doi.org/10.24832/jpnk.v4i1.1157

Rasidi, M. A., \& Setiawati, F. A. (2015). Faktor-Faktor Kesulitan Guru pada Pembelajaran Tematik Integratif di SD Kota Mataram. Jurnal Prima Edukasia, 3(2), 155-165. https://doi.org/10.21831/jpe.v3i2.6504

Sakti, B. P., \& Wijayanti, W. (2014). Implementasi Pembelajaran Tematik pada SDN di Gugus III Kecamatan Kalasan Kabupaten Sleman DIY. Jurnal Prima Edukasia, 2(1), 14-26. https://doi.org/10.21831/jpe.v2i1.2641

Sutjipto, S. (2016). Pentingnya Pelatihan Kurikulum 2013 Bagi Guru. Jurnal Pendidikan dan Kebudayaan, 1(2), 235-260. https://doi.org/10.24832/jpnk.v1i2.771

Trianto. (2014). Model Pembelajaran Terpadu. Konsep Strategi dan Implementasinya Dalam KTSP.

Trilling, B. dan Fadel, C. (2010). $21^{\text {st }}$ Century Skills: Learning for Life in Our Times. Choice Reviews Online. https://doi.org/10.5860/choice.47-5788

UU RI NO 20. (2003). Undang-Undang Republik Indonesia Nomor 20 Tahun 2003 tentang Sistem Pendidikan Nasional dengan Rahmat Tuhan yang Maha Esa Presiden Republik Indonesia.

Yin, R. K., \& K.Yin, R. (2011). Qualitative Research from Start to Finish. In The Guilford Press. https://doi.org/10.1017/CBO9781107415324.004 